\title{
AMPLITUDE AND RECOVERY VELOCITY OF RELAXATION INDUCED BY RECTOANAL INHIBITORY REFLEX AND ITS IMPORTANCE FOR OBSTRUCTIVE EVACUATION
}

\author{
João Gomes NETINHO ${ }^{1}$, Maria de Lourdes Setsuko AYRIZONO², \\ Cláudio Saddy Rodrigues COY $^{3}$, João José FAGUNDES ${ }^{2}$ and Juvenal Ricardo Navarro GÓES ${ }^{2}$
}

\begin{abstract}
Background - The rectoanal inhibitory reflex has an important rule in the fecal continence mechanism. Alterations in this reflex can be associated with compromised anal sphincteric function. Aim - To identify possible correlation between rectoanal inhibitory reflex parameters and intestinal constipation due to obstructive evacuation. Patients - Sixty nine patients with intestinal constipation had been submitted to anorectal manometry. It was selected 29 patients (27 female, mean age of 42.3 (19-73) years) having intestinal constipation owing to obstructive evacuation. Thirteen individuals without anorectal functional complaints (eight female, mean age 52.5 (28-73) years) formed the control group. Results - The mean value of resting anal pressure before rectoanal inhibitory reflex in the proximal and distal anal canals were $61.8 \mathrm{~mm} \mathrm{Hg}$ and $81.7 \mathrm{~mm} \mathrm{Hg}$ respectively, for the constipated patients, and $46.0 \mathrm{~mm} \mathrm{Hg}$ and $64.5 \mathrm{~mm} \mathrm{Hg}$, respectively, for asymptomatic individuals. The mean pressure at the point of maximal relaxation in constipated patients was $29.0 \mathrm{~mm} \mathrm{Hg}$ in the proximal anal canal, and $52.1 \mathrm{~mm} \mathrm{Hg}$ in the distal anal canal, whilst in the asymptomatic group they were $17.8 \mathrm{~mm} \mathrm{Hg}$ and $36.3 \mathrm{~mm} \mathrm{Hg}$, respectively. The mean percentage difference between the mean resting anal pressure and the mean point of maximal relaxation pressure in the proximal anal canal (amplitude of relaxation) was 54.1\% in constipated patients and 54.3\% in asymptomatic individuals. In the distal anal canal it was, respectively, $35.6 \%$ in constipated patients, and $38.5 \%$ in the control group. The average recovery velocity of relaxation in the proximal anal canal was $4.06 \mathrm{~mm} / \mathrm{second} \mathrm{in} \mathrm{constipated} \mathrm{patients} \mathrm{and} 2.98 \mathrm{~mm} / \mathrm{second} \mathrm{in} \mathrm{asymptomatic} \mathrm{individuals,} \mathrm{giving} \mathrm{a} \mathrm{significant} \mathrm{difference}$ between the two groups, as well as in the distal anal canal $(3.9 \mathrm{~mm} / \mathrm{second}$ and $2.98 \mathrm{~mm} / \mathrm{second}$, respectively) Conclusion - The greater recovery velocity of the resting anal pressure in the proximal anal canal in constipated patients than in controls may be associated with obstructive evacuation.
\end{abstract}

HEADINGS - Constipation. Defecation, physiology. Anus, physiopathology.

\section{INTRODUCTION}

Constipation is a common complaint, which affects individuals of all age groups. In the United States of America, the prevalence of constipation is estimated between $2 \%$ and $28 \%$ of the population, and it is responsible for 2.5 million doctor appointments per year, confirming that only a minority seeks medical assistance ${ }^{(5,7,12)}$.
Several factors contribute to the occurrence of intestinal constipation, including low socioeconomic level, age, gender, insufficient consumption of vegetal fibers in the diet, and the life style in industrialized countries ${ }^{(1,2)}$. Some medicines and psychiatric alterations are also associated with its genesis ${ }^{(3,6)}$.

However, in more than half the cases no organic cause for constipation can be identified. In this case it is called functional intestinal constipation. This may be associated with deficient

${ }^{1}$ Discipline of Coloproctology, Department of Surgery, Hospital de Base, São José do Rio Preto Medical School, São José do Rio Preto, SP, Brazil; ${ }^{2}$ Department of Digestive Surgery of the State University of Campinas, Campinas, SP, Brazil

Address for correspondence: Dr. João Gomes Netinho - Rua San Francisco, 481 - Condominio Débora Cristina - 15093-030 - São José do Rio Preto, SP, Brazil. e-mail: jgnetinho@riopreto.com.br 
propulsion of the fecal contents through the colon (colonic inertia) or difficulty to eliminate the rectal contents, where in this case there is a functional alteration in the defecation mechanism (obstructive defecation).

Rectoanal inhibitory reflex (RAIR) is considered to play an important role in the mechanism of evacuation ${ }^{(9,11)}$. Nevertheless, few investigations have been published aiming to evaluate RAIR and the significance of its different phases. Although there are some published works that discuss aspects linked to the RAIR, in normal, constipated and incontinent individuals, it can be confirmed that the intensity of relaxation, which is the main component of this reflex and other characteristics, have not yet been duly evaluated. WILLIAMSON et al. ${ }^{(14)}$ utilizing a helicoidal perfusion catheter demonstrated that there is an asymmetry of RAIR along the longitudinal axis of the anal canal and observed that there is a gradual reduction in the intensity of relaxation towards the distal segment during reflex itself. In normal volunteers, GÓES et al..$^{(4)}$ confirmed that the intensity and duration of relaxation is greater in the anal canal proximal segment than in the high-pressure zone especially from the point of maximal relaxation (PMR) when the recovery time of RAIR is greater in the proximal anal canal than in the distal. ZBAR et al. ${ }^{(15)}$ compared maximum inhibitory pressures in RAIR and verified that they were consistently higher along the entire anal canal in constipated patients than in both apparently healthy and incontinent voluntaries.

This study compares constipated patients with obstructive defecation and volunteers without anorectal symptoms in relation to the behavior of the sphincteral relaxation, especially its intensity and the recovery velocity $(\mathrm{RV})$ of the basal tonus from the PMR, both in the proximal and distal segments of the anal canal.

\section{PATIENTS AND METHODS}

This retrospective study analyzed previously performed examinations recorded on cassettes in the Anorectal Physiology Laboratory of the Digestive Tract Disease Department (GASTROCENTRO - School of Medical Sciences, State University of Campinas (UNICAMP)), Campinas, SP, Brazil. This study was submitted to and approved by the Ethics Research Committee of the institution.

Initially 69 examinations of patients suffering from chronic intestinal constipation were analyzed. The possibility of constipation from an organic etiology was discarded in all cases using clinical data collected at anamnesis and with the systematic use of laboratorial examinations including tests of glycemia, calcium, TSH and free thyroxine. Where the possibility of Chagas' disease was suspected, the Machado-Guerreiro test was also performed. Anatomic studies of the rectum and colon were also obtained by barium enema, colonoscopy or in some cases by rectosigmoidoscopy thereby excluding the possibility of intestinal stenosis. Positive results in any of the aforementioned examinations identified constipation of an organic etiology and led to the exclusion of the patient from the work. In the rest of the patients, functional tests were made. The first was the colonic transition time (CTT) followed by anorectal manometry and video defecography. In the CTT test, patients in whom more than $20 \%$ of the markers remained in the rectosigmoid were included and the other patients were excluded from the study. All these patients in whom the markers remained in the rectosigmoid (29) complained of difficulties to evacuate, requiring excessive force and sometimes needing vaginal digitations or a long time to eliminate the contents of the rectum. Others even complained of a sensation of incomplete evacuation. The video defecography in this group of patients always revealed an alteration associated with obstructive defecation, such as rectocele (18 cases), paradoxical contraction of the puborectal muscle ( 7 cases), rectal intussusception ( 2 cases) or megarectum (2 cases). There were no cases of enterocele or sigmoidocele. Thus 27 female and 2 male patients with a mean age of 42.3 years (range 19-73 years) were selected and constituted the study group.

A control group was formed by the selection of examinations of patients presenting with anal pruritus or any other complaint not related to anorectal functional alterations. This group was considered to be asymptomatic from the functional point of view and constituted of 13 individuals ( 8 female and 5 male) with an average age of 42.3 (range 19-73) years.

All the individuals were submitted to anorectal manometry, with special emphasis on RAIR. The anorectal manometry apparatus consists of a pneumo-hydraulic perfusion system, which perfuses distilled water at velocity of 25 milliliters per minute (Arndorfer ${ }^{\mathrm{TM}}$, Inc., Greenvale, WI, USA). This is connected to a computerized system utilizing a catheter with eight helicoidally-positioned channels connected to a IBM-compatible PC computer with commercially available software (Gastrosoft $^{\mathrm{TM}}$, Polygram Lower GI ${ }^{\mathrm{TM}}$, version 6.40, Synectics Medical ${ }^{\mathrm{TM}}$ Inc., Irwing, TX, USA).

The following parameters, both in the proximal and distal segments of the anal canal, were analyzed: mean resting anal pressure (RAP) pre-elicitation of relaxation; pressure at the PMR; difference between the RAP and the PMR and the RV of the anal pressure in the proximal and distal segments calculated by the slope of a tangent on the anorectal manometry trace (determined by the computer software - Figure 1).

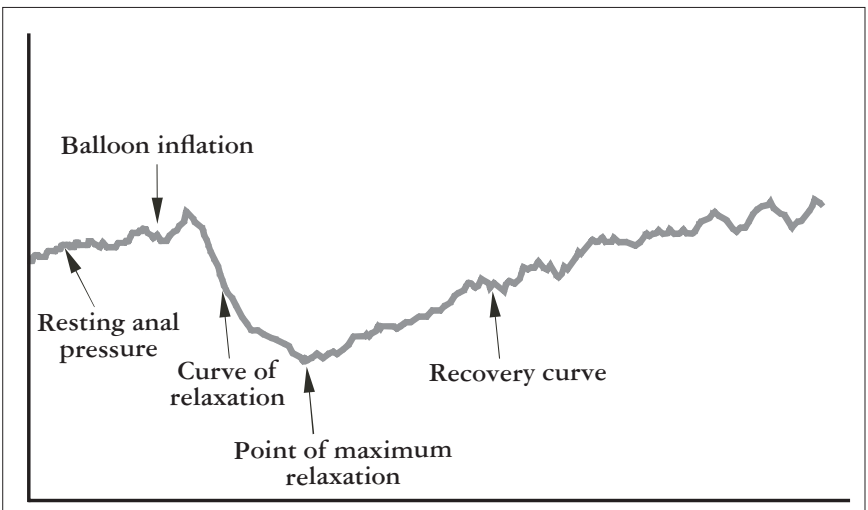

FIGURE 1 - Rectoanal inhibitory reflex

It was assumed as the proximal anal canal the more proximal registration of anal motility as well the registration of the rectoanal inhibitory reflex, being present all the parameters of interest in this study. Similarly, distal anal canal was the more distal documentation of those parameters. Some patients with very short anal canal had the proximal registration very close to the distal one.

A comparative study between constipated patients and control individuals of the parameters relating to RAIR was performed in the following sequence: percentage of proximal and distal relaxation in normal individuals; percentage of proximal and distal relaxation in constipated patients; percentage of proximal and distal relaxation between 
Netinho JG, Ayrizono MLS, Coy CSR, Fagundes JJ, Góes JRN. Amplitude and recovery velocity of relaxation induced by rectoanal inhibitory reflex and its importance for obstructive evacuation

constipated and normal individuals; recovery velocity of the proximal and distal resting anal pressure in normal individuals; recovery velocity of the proximal and distal resting anal pressure in constipated patients; recovery velocity of the distal resting anal pressure between constipated and normal individuals: and recovery velocity of the distal resting anal pressure between constipated and normal individuals. Anal pressure was a mean value obtained from the software of the computer. As the catheter used was static and helicoidally positioned the mean value was the addition of the sequential values during the time duration of the observation.

These comparisons were statistically analyzed utilizing the two-tailed Wilcoxon test for parametric and non-parametric variables. The significance level for statistical validation was considered for a $P$-value $\leq 0.05$.

\section{RESULTS}

The mean values of pre-elicited RAP of RAIR in the proximal anal canal of the constipated group was $61.8 \mathrm{~mm} \mathrm{Hg}$ and in the control group it was $46.0 \mathrm{~mm} \mathrm{Hg}$.

The mean values of pre-elicited RAP of RAIR in the distal anal canal of the constipated group was $81.7 \mathrm{~mm} \mathrm{Hg}$ and in the control group it was $64.5 \mathrm{~mm} \mathrm{Hg}$.

The mean PMR in the proximal segment was $29.0 \mathrm{~mm} \mathrm{Hg}$ in the constipated group and $17.8 \mathrm{~mm} \mathrm{Hg}$ in the control group whilst in the proximal segment they were $52.1 \mathrm{~mm} \mathrm{Hg}$ and $36.3 \mathrm{~mm} \mathrm{Hg}$, respectively.

The average difference between the mean RAP and PMR in the proximal segment of constipated patients was $54.1 \%$ and in the control group $54.3 \%$, whilst in the distal segment the differences were $35.6 \%$ and $38.5 \%$ respectively.

The mean RV of relaxation of the proximal anal canal in constipated patients was $4.06 \mathrm{~mm} / \mathrm{second}$ and in the control group it was $2.98 \mathrm{~mm} /$ second while in the distal portion of the anal canal the means were 3.9 vs. $2.3 \mathrm{~mm} / \mathrm{second}$, respectively (Figure 2).

Analyses of the parameters related to RAIR showed a significantly greater percentage of relaxation in the proximal than in distal anal canal in the asymptomatic individuals (mean values $54.3 \%$ vs. $38.5 \% ; P=$ $0.003)$. A similar situation was evidenced in the constipated patients (mean $54.1 \%$ vs. $35.6 \% ; P$-value 0.0001 ).

There was no statistical difference between the constipated and normal individuals in the proximal anal canal relaxation (mean $54.1 \%$ vs. $54.3 \%$, respectively; $P$-value $=0.9$ ). The same was seen with the distal segment (mean $35.6 \%$ vs. $38.5 \%$, respectively; $P$-value $=0.93$ ).

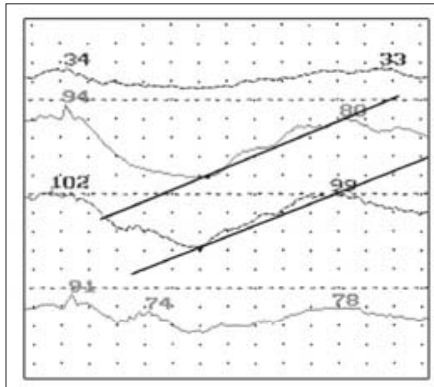

A

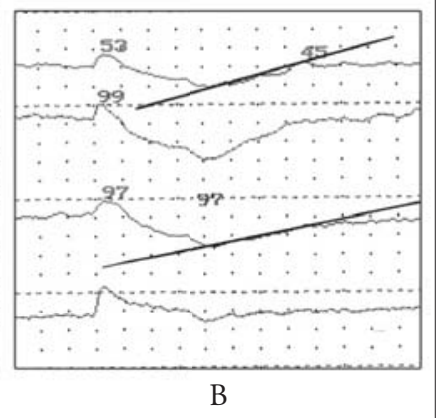

B
FIGURE 2 - Trace of the RAIR showing that the recovery of the proximal relaxation was faster in constipated patients (A) when compared with normal individuals (B) with mean velocity of $4.06 \mathrm{~mm} / \mathrm{second}$ and $2.98 \mathrm{~mm} / \mathrm{second}$, respectively

The recovery velocity of the relaxation did not present significant difference between the proximal and distal segments of the anal canal (mean $2.98 \mathrm{~mm} /$ second vs. $2.33 \mathrm{~mm} /$ second, respectively; $P$-value $=$ $0.46)$ in the control group individuals. The same was evidenced in the constipated subjects (mean $4.06 \mathrm{~mm} / \mathrm{second}$ vs. $3.9 \mathrm{~mm} / \mathrm{second}$ proximal and distal, respectively; $P$-value $=0.58)($ Figure 3$)$.

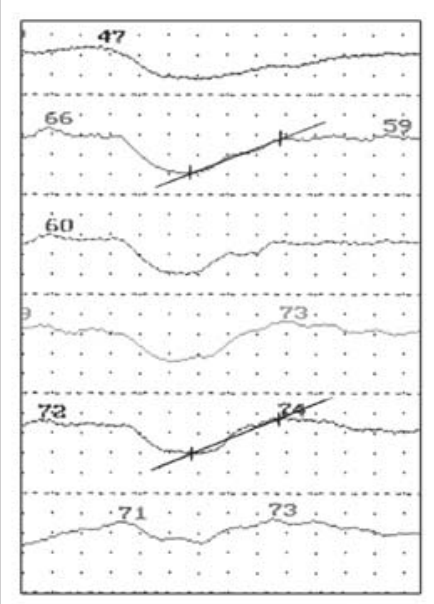

A

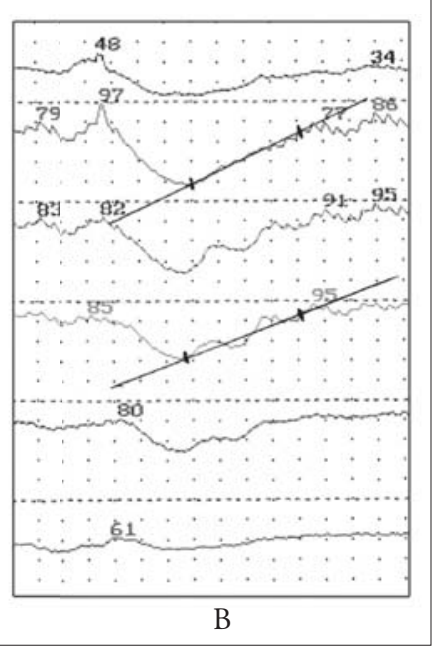

FIGURE 3 - Trace of the RAIR demonstrating a faster relaxation recovery velocity in the proximal portion $(2.98 \mathrm{~mm} /$ second $)$ is statistically similar to the distal portion $(2.33 \mathrm{~mm} / \mathrm{second})$ of the anal canal in normal individuals (A). This was similar in constipated patients (B) $(4.06 \mathrm{~mm} / \mathrm{second}$ and 3.90 $\mathrm{mm} /$ second, respectively)

Analyses of the parameters related to RAIR showed a significantly greater percentage of relaxation in the proximal than in distal anal canal in the asymptomatic individuals (mean values $54.3 \%$ vs. $38.5 \%$; $P=$ $0.003)$. A similar situation was evidenced in the constipated patients (mean $54.1 \%$ vs. $35.6 \%$; $P$-value 0.0001 ).

There was no statistical difference between the constipated and normal individuals in the proximal anal canal relaxation (mean $54.1 \%$ vs. $54.3 \%$, respectively; $P$-value $=0.9)$. The same was seen with the distal segment (mean $35.6 \%$ vs. $38.5 \%$, respectively; $P$ value $=0.93$ )

The recovery velocity of the relaxation did not present significant difference between the proximal and distal segments of the anal canal (mean $2.98 \mathrm{~mm} /$ second vs. $2.33 \mathrm{~mm} /$ second, respectively; $P$-value $=$ $0.46)$ in the control group individuals. The same was evidenced in the constipated subjects (mean $4.06 \mathrm{~mm} / \mathrm{second}$ vs. $3.9 \mathrm{~mm} / \mathrm{second}$ proximal and distal, respectively; $P$-value $=0.58)($ Figure 3$)$.

On the other hand, the recovery velocity of the relaxation of the proximal anal canal was significantly faster in constipated patients than in normal individuals (mean $4.06 \mathrm{~mm} / \mathrm{second}$ vs. $2.98 \mathrm{~mm} / \mathrm{second} ; P$ value 0.002) (Figure 4). The same was evidenced in the distal portion of the anal canal (mean $3.90 \mathrm{~mm} / \mathrm{second}$ vs. $2.33 \mathrm{~mm} / \mathrm{second}$; $P$-value $=0.015)($ Figure 5).

\section{DISCUSSION}

This study was made to analyze the behavior of anal pressures during relaxation pre-elicited by RAIR, more specifically from the PMR to the 
Netinho JG, Ayrizono MLS, Coy CSR, Fagundes JJ, Góes JRN. Amplitude and recovery velocity of relaxation induced by rectoanal inhibitory reflex and its importance for obstructive evacuation

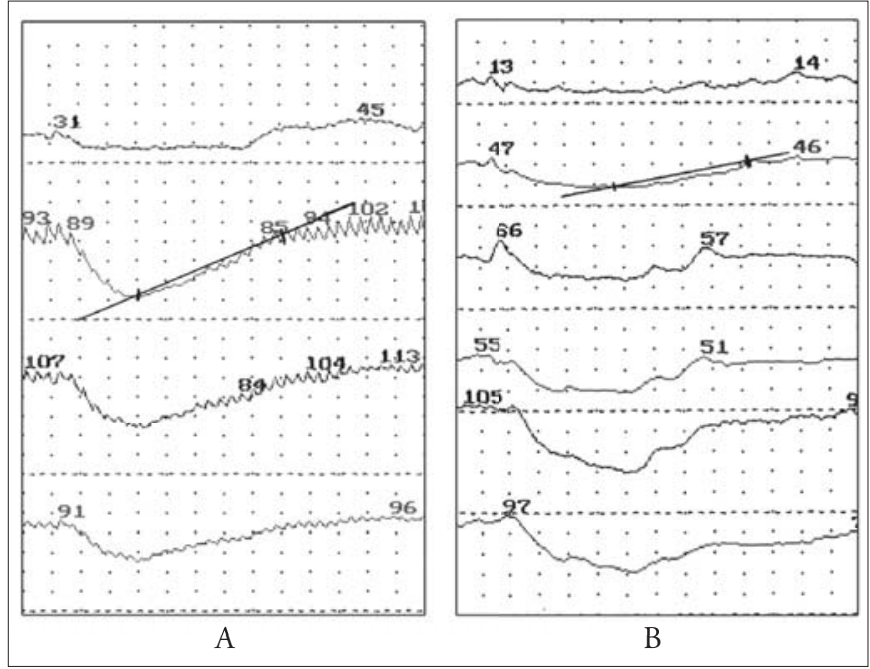

FIGURE 4 - Trace of the RAIR demonstrating a faster relaxation recovery velocity in the proximal portion of the anal canal in constipated patients (A) than in normal individuals (B) with mean velocity of $4.06 \mathrm{~mm} / \mathrm{second}$ and $2.98 \mathrm{~mm} / \mathrm{second}$, respectively

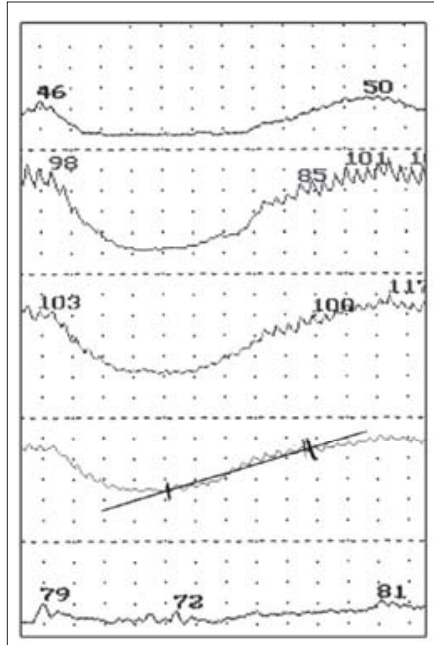

A

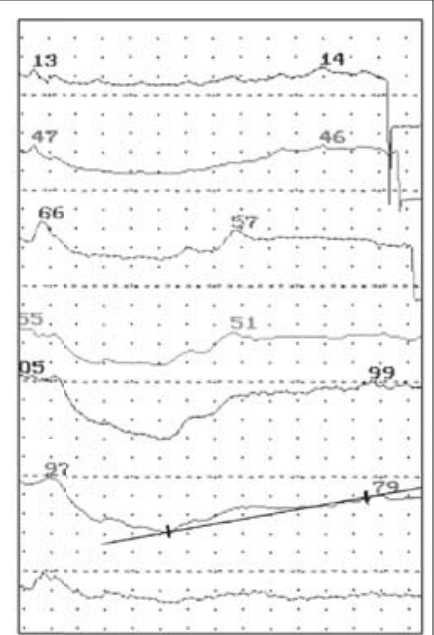

B
FIGURE 5 - Trace of the RAIR demonstrating a faster relaxation recovery velocity in the proximal portion of the anal canal in constipated patients (A) than in normal individuals (B) with mean velocity of $3.90 \mathrm{~mm} / \mathrm{second}$ and 2.33 $\mathrm{mm} /$ second, respectivel

moment of basal RAP recovery. These analyses were performed in the proximal and distal segments of the anal canal, comparing constipated patients with obstructed evacuation and asymptomatic individuals. Hence, the pressure level at the PMR in both the proximal and distal segments in constipated and normal individuals, as well as the RV of RAP, were studied.

It is known that the external anal sphincter (EAS) and internal anal sphincter (IAS) envelop the anal canal and are responsible for maintaining resting and generating squeeze pressures. There is a graduated increase in pressure from proximal to distal in the anal canal. The relative contribution of the IAS and the EAS to maintaining resting pressure is difficult to determine because the muscles overlap. Experimentally blocking the pudendal nerve, which results in loss of EAS tone, however, has shown that the IAS contributes up to 85 percent of resting tone.

The behavior of the motility of the anal canal after the elicitation of RAIR was studied, and it was demonstrated that anal sphincter relaxation in constipated patients was more accentuated proximally than distally in the anal canal in the same way as was observed in normal individuals, as previously reported by WILLIAMSON et al. ${ }^{(14)}$. GÓES et al. ${ }^{(11)}$ in a study of individuals without anorectal symptoms demonstrated that, both the amplitude and duration of relaxation was longer in the proximal anal canal compared to the distal anal canal.

However, when this relaxation is compared between constipated patients with obstructive defecation and normal controls, no significant differences were observed in the percentage of sphincter relaxation both in the proximal and distal segments. ZBAR et al. ${ }^{(15)}$ studying the motility of the anal canal concluded that the amplitude and relaxation did not significantly differ among normal individuals, patients with incontinence and those with intestinal constipation.

It is known that RAIR is not essential for defecation, but insufficient relaxation of the internal anal sphincter has been associated with the pathogenesis of constipation ${ }^{(10)}$. LOENING-BAUCKE ${ }^{(8)}$ reported that children with idiopathic megacolon and megarectum present with less relaxation of the internal anal sphincter in response to rectal distension. This has also been reported in patients with long-evolution constipation in whom a significantly greater electrical stimulus was necessary to induce maximum relaxation ${ }^{(15)}$.

In this current study, the behavior of the anal canal of patients suffering from obstructive-type constipation did not show insufficient intensity of relaxation; in fact, relaxation was not different when compared with normal individuals. This suggests that the intensity of relaxation of the internal anal sphincter, both in the proximal and distal segments of the anal canal, does not interfere with the evacuation mechanism of patients with obstructive constipation.

Another parameter studied was the RV of the RAP in normal individuals and patients with chronic constipation due to the involvement of the defecation mechanism.

In individuals belonging to the control group, the RV of the RAP is greater in the proximal segment than in the distal segment, but without statistical difference. A similar situation was confirmed in constipated patients in whom the RV of the basal tonus also presented with higher values in the proximal segment compared with the distal segment but again without statistically significant differences.

ZBAR et al. ${ }^{(12)}$ demonstrated that the recovery time of the distal sphincter is faster than the proximal and, additionally, it is even more rapid in incontinent patients than in constipated patients, suggesting a coordinated inhibitory response by the sphincter. The same was confirmed by GÓES et al. ${ }^{(4)}$ in individuals without anorectal alterations, whose duration of relaxation of the proximal anal canal was greater than in the distal segment.

However, on comparing the RV between constipated patients and the control group, a greater RV of the RAP was confirmed both in the proximal and distal segments of constipated patients with statistically significant differences. From the functional point of view, this greater RV of the resting tonus postelicitation by RAIR may be related to a greater tendency of the proximal and distal segments of the anal canal to close in patients suffering from obstructive evacuation. This would explain the difficulty of defecation. 
Despite of this finding being in agreement with visual analysis of the manometry traces, there is a necessity to find a more precise graphic means to confirm this. A great difficulty arises in the definition of the reference points on the trace to define the straight line for the slope of the curve and, from which the RV can be established. On considering the closeness of the RV values obtained in the proximal and distal segments, in both constipated and normal individuals, difficulties to interpret using a physiological basis to perform statistical analyses becomes apparent. What can be deduced from these confirmations is that new attempts to obtain these data in a better way will be fundamental to better correlate them to the physical events present in RAIR.

In conclusion, within the methodological limitations proposed by this study, it was confirmed that, both in patients with intestinal constipation due to obstructive evacuation and normal individuals, the proximal relaxation is more accentuated than the distal relaxation.
The same is seen when comparing the relaxation RV in the proximal segment compared to the distal segment. It is possible to infer that the behavior of the anal canal in patients suffering from obstructive-type constipation does not demonstrate insufficient relaxation as there is no significant difference when compared with the individuals of the control group. This suggests that the intensity of internal anal sphincter relaxation, both in the proximal and distal anal canals does not interfere with the evacuation mechanism in patients suffering from constipated due to obstructive evacuation.

More important in the understanding of the possible participation of RAIR in this type of constipation, is the observation that in the group of constipated patients, the RV of the basal tonus was faster than in the asymptomatic individuals, both in the proximal and distal segments. This demonstrates a greater tendency of early closure of the anal canal in constipated patients.

Netinho JG, Ayrizono MLS, Coy CSR, Fagundes JJ, Góes JRN. Amplitude e recuperação da velocidade do relaxamento induzida pelo reflexo inibitório retoanal e sua importância na evacuação obstrutiva. Arq Gastroenterol 2005;42(1):19-23.

RESUMO - Racional - A constipação intestinal é queixa muito freqüente, sendo o motivo de grande número de consultas médicas. No entanto, apesar dos avanços na compreensão da fisiologia anorretocólica, ainda representa problema clínico de difícil solução. Objetivo - Identificar possível correlação entre dados fisiológicos presentes no reflexo inibitório retoanal e a constipação intestinal por evacuação obstruída. Material e Métodos - Foram selecionados 69 exames de pacientes, submetidos previamente a manometria anorretal no Laboratório de Fisiologia Anorretal da Faculdade de Ciências Médicas da Universidade Estadual de Campinas, Campinas, SP. Destes, após serem aplicados os critérios de exclusão e inclusão, foram selecionados 29 pacientes com constipação intestinal por evacuação obstruída, sendo 27 do sexo feminino e média de idade de 42,3 (19-73) anos. Da mesma forma, foram selecionados 13 indivíduos sem queixas funcionais anorretais, sendo 8 do sexo feminino, com média de idade de 52,5 (28-73) anos. No reflexo inibitório retoanal foi analisada a pressão anal de repouso média, o ponto de máximo relaxamento e a velocidade de recuperação até atingir a pressão basal, todos nos níveis proximal e distal do canal anal. A seguir foi realizado o estudo comparativo entre esses dados. Resultados - O valor médio da pressão anal de repouso média pré-indução do reflexo inibitório retoanal no nível proximal foi, nos pacientes constipados, de $61,8 \mathrm{~mm} \mathrm{Hg}$ e no nível distal, $81,7 \mathrm{~mm} \mathrm{Hg}$, enquanto que nos assintomáticos encontraram-se 46,0 $\mathrm{mm} \mathrm{Hg}$ e $64,5 \mathrm{~mm} \mathrm{Hg}$, respectivamente, para os níveis proximal e distal. A média da pressão no ponto de máximo relaxamento nos pacientes constipados foi $29,0 \mathrm{~mm} H \mathrm{Hg}$ no nível proximal do canal anal e $52,1 \mathrm{~mm} \mathrm{Hg}$ no nível distal, enquanto que no grupo de assintomáticos foi $17,8 \mathrm{~mm} \mathrm{Hg}$ e $36,3 \mathrm{~mm} \mathrm{Hg}$, respectivamente, no canal anal proximal e no distal. A média da diferença percentual entre a pressão anal de repouso média e a pressão no ponto de máximo relaxamento no nível proximal, que indicou a amplitude do relaxamento, foi $54,1 \%$ nos constipados e $54,3 \%$ nos assintomáticos. No nível distal, a média da diferença foi $35,6 \%$ nos constipados e $38,5 \%$ no grupo-controle. A média da velocidade de recuperação no nível proximal foi $4,06 \mathrm{~mm} / \mathrm{seg}$. nos constipados e 2,98 mm/seg nos assintomáticos, sendo a diferença entre as duas estatisticamente significativa. A média da velocidade de recuperação no grupo de constipados no nível distal do canal anal foi $3,9 \mathrm{~mm} / \mathrm{seg}$. e $2,98 \mathrm{~mm} / \mathrm{seg}$. nos normais, sendo a diferença entre as duas também significativa do ponto de vista estatístico. Conclusão - A amplitude de relaxamento, apesar de ser maior no canal anal proximal tanto em constipados, como em controles normais, não parece ter participação no mecanismo da evacuação obstruída. A maior velocidade de recuperação da pressão de repouso em nível proximal em constipados do que em controles normais pode estar associada à condição de evacuação obstruída, uma vez que o canal anal tenderá mais rapidamente ao fechamento na sua porção proximal e, portanto, a maior dificuldade de iniciar a evacuação.

DESCRITORES - Constipação. Defecação, fisiologia. Ânus, fisiopatologia.

\section{REFERENCES}

1. Briejer MR, Schuurkes JA, Sarna SK. Idiopathic constipation: too few stools and too little knowledge. Trends Pharmacol Sci 1999;20:1-3.

2. Burkitt DP, Walker AR, Painter NS. Effect of dietary fiber on stool and transit-time and its role in the causation of disease. Lancet 1972;30:1408-12.

3. Devroede G. Constipation. In: Sleisinger MH, Fordtran JS, editors. Gastrointestinal disease: pathophysiology, diagnosis, treatment. $5^{\text {th }}$ ed. Philadelphia: WB Saunders; 1993. p.837-87.

4. Góes RN, Simons AJ, Masri L, Beart RW Jr. Gradient of pressure and time between proximal anal canal and high-pressure zone during internal anal sphincter relaxation: its role in the fecal continence mechanism. Dis Colon Rectum 1995;38:1043-6.

5. Golden WE, Hopkins RH. Constipation. Internal Medicine News Online 2001;34:1-3.

6. Keighley MRB. Constipation. In: Keighley MRB, Williams NS. Surgery of the anus, rectum and colon. London: WB Saunders; 1993. p.609-38.

7. Locke GR, Pemberton JH, Phillips SF. AGA technical review on constipation. Gastroenterology 2000;119:1766-78.

8. Loening Baucke VA. Abnormal rectoanal function in children recovered from chronic constipation and encopresis. Gastroenterology 1984;87:1299-304.

9. O'Riordain MG, Molloy RG, Gillen P, Horgan A, Kirwan WO. Rectoanal inhibitory reflex following low stapled anterior resection of the rectum. Dis Colon Rectum 1992; 35(9): 874-8.
10. Sangwan YP, Solla JA. Internal anal sphincter - advances and insights. Dis Colon Rectum 1998;41:1297-311.

11. Shafik A, El-Sibai, Ahmed I. Parasympathetic extrinsic reflex: role in defecation mechanism. World J Surg 2002;26:737-40.

12. Sonnenberg A, Koch TR. Epidemiology of constipation in the United States. Dis Colon Rectum 1989;32:1-8.

13. Thompson WG, Longstreth GF, Drossman GF, Heaton KW, Irvine EJ, Müller-Lissner AS. Functional bowel disorders and functional abdominal pain [Rome II: A Multinational Consensus Document on Functional Gastrointestinal Disorders]. Gut 1999;45 suppl II:1143-7.

14. Williamson JL, Nelson RL, Orsay C, Pearl RK, Abcarian H. A comparison of simultaneous longitudinal and radial recordings of anal canal pressures. Dis Colon Rectum 1990;33:201-6.

15. Zbar AP, Aslam M, Gold DM, Gatzen C, Gosling A, Kmiot WA. Parameters of the rectoanal inhibitory reflex in patients with fecal incontinence and chronic constipation. Dis Colon Rectum 1998;41:200-8. 